\title{
Oral Surgery in the Human Microbiota Era the role of Periodontal Bacteria
}

\author{
Germano Orrù ${ }^{1 *}$, Vincenzo Piras ${ }^{2}$, Gloria Denotti ${ }^{2}$, Cristina Demontis ${ }^{2}$, Alessandra Scano ${ }^{1}$, Ferdinando Coghe ${ }^{3}$, \\ Giuseppe Speziale ${ }^{4}$, Claudio Napoleone ${ }^{5}$, Abdallah Raweh ${ }^{6}$ and Andrea Mascolo ${ }^{6 *}$
}

${ }^{1}$ Molecular Biology Service-AOU-Cagliari, Italy

${ }^{2}$ Institute of Dentistry, University of Cagliari, Italy

${ }^{3}$ Hospital University Laboratory Service -AOU Cagliari, Italy

${ }^{4}$ CardioSurgery Department - Anthea Hospital - Bari, Italy

${ }^{5}$ Dental Operative Unit - Villa Lucia Hospital- Conversano (BA)- Italy

${ }^{6}$ LUDES Foundation H.E.I.- Malta

Submission: March 28, 2017; Published: March 30, 2017

*Corresponding author: Germano Orrù, Molecular Biology Service-AOU-Cagliari, Italy; Email: orru@unica.it Andrea Mascolo, Associate Professor, LUDES Foundation HEI, Malta, Italy; Email: andrea.mascolo@ludes.edu.mt

\section{Mini Review}

\section{System biology and Human microbiota}

Recent studies have highlighted the oral cavity as a complex biological system organized into several micro and nanoscopic scales, as described by an interdisciplinary field of study using a holistic approach. In this context the recent introduction of the technology of Next Generation Sequencing (NGS) has shed new light on human genomics, but,more especially, has increased the knowledge of the bacterial populations normally resident in the human tissues and called microbiota. NGS, also known as high-throughput sequencing, is a procedure that is able to perform the sequencing in a few hours of both the entire human genome and also the complete profile of the ribosomal gene set or certain genes of interest related to a specific microbiota (metagenomics). Many human tissues, such as the skin, oral cavity, nose, upper air-ways, stomach, lower intestine, and the genito-urinary tract, are colonized by resident populations of bacteria. This complex microbial community performs many essential functions, including a protective effect in preventing opportunistic infections through the competitive exclusion of pathogenic species or by modulating the immune response in the host. In other cases it provides a fundamental contribution to normal functioning in its ecological area (tissue) i.e.in the digestive function in the gastro intestinal tract. The microbiotas in the healthy subjects must be in a strict range of homeostasis with the tissues in which they exist. In fact, the reasons why these bacterial communities could be harmful in humans is that a group of some opportunistic bacteria can infect body areas, normally free from microbial colonization, as a result of normal host defenses being compromised. In particular, in oral microbiota we find a group of anaerobic bacteria that are historically related to periodontal disease, which according to the latest research, are able to invade other body regions or organs from the oral district. The latest evidence shows that these severe infections were most likely a consequence of a bacteremia from oral tissues due to surgical acts or caused in patients after oral hygiene procedures, such as tongue scraping [1].

The vengeance of periodontal bacteria "only for aesthetic effect"

Table 1: Non-oral diseases related to some periodontal bacteria.

\begin{tabular}{|c|c|c|}
\hline Species name & Sonkransky complex & Related non-oral disease \\
\hline Aggregatibacter actinomycetemcomitans & Green & Endocarditis [10,11], Rheumatoid arthritis [12] \\
\hline Campylobacter rectus & Orange & Cardiovascular diseases [13], thoracic empyema [14] \\
\hline Fusobacterium nucleatum & Orange & Preterm birth [15], Colon cancer [16], Oral cancer [17,18] \\
\hline Porphyromonas gingivalis & Red & $\begin{array}{c}\text { Rheumatoid arthritis [19], Atherosclerosis [5,20], Endocarditis [21], Oral } \\
\text { cancer [17] }\end{array}$ \\
\hline Prevotella intermedia & Orange & Cardiovascular diseases [22] \\
\hline Tannerella forsythia & Red & Cardiovascular diseases [23], Atherosclerosis [24] \\
\hline Treponema denticola & Red & Cardiovascular diseases [25], Alzheimer's disease [26] \\
\hline
\end{tabular}


In the 1990s Sigmund Socransky published a fundamental work, in which he used association criteria in healthy and diseased subjects to categorize the bacterial species involved in the initiation and progression of periodontal disease. He divided the several complexes of bacteria into groups and labeled them with colors, the categories were based upon the association with the disease (Table 1). 25 years after this publication some crucial new information has been discovered about these anaerobic bacteria:

(i) In oral healthy subjects, they are normally localized on the tongue dorsum in a large and extensive biofilm, as well as in the saliva [2].

(ii) The percentage of these bacteria in the oral cavity is strictly linked with the patient's habits, such as a diet rich in meat or smoking $[3,4]$.

(iii) the latest works report them as etiological agents in systemic infective-inflammatory or in autoimmune diseases such as rheumatoid arthritis and in atheromatous plaques [5-7], infective endocarditis and some researchers have recently suggested their role in neurogenerative diseases such as Alzheimer's disease [8], while it is certain that $F$. nucleatum is associated with intestinal cancer.

This data suggests that the anaerobic bacteria resident in tongue microbiota play a direct-indirect role in modernday diseases due to our different habits as compared to our ancestors. In fact, recent works comparing the teeth microbiota in hundred-year old samples and present-day ones have demonstrated a substantial difference for these bacteria, especially in the Sonkransky red complex, where the modernday subjects exhibited a 100-fold increase in the percentage of red complex bacteria titer in the tooth calculus as compared to the old samples [9]. For such reasons, the increase in oral anaerobic bacteria in modern-day subjects, probably caused by different habits such as modern diet, can implement the risk for modern degenerative diseases.

\section{Oral surgery and risk for bacteremia}

The incidence of bacteremia and related systemic diseases due to oral anaerobic bacteria following different procedures such as: endodontic treatment, tooth extraction, periodontal surgery, tongue scraping and root scaling has been well documented [10-27] and anaerobe periodontal bacteria are isolated more frequently than facultative anaerobic bacteria, such as Streptococcus spp. [28]. Transitory bacteremia is detectable from 100 to $50 \%$ in healthy subjects after surgical acts, for example: dental extraction, tonsillectomy or third-molar surgery respectively. Surgical procedure could substantially increase the risk for oral bacteria systemic dissemination for three different reasons:

(i) mechanical breaking-down of the mucosa barriers for microorganisms, i.e. surface epithelium, immunological barrier of antibody-forming cells and defensins, (ii) non- effective use of antimicrobial agents during the surgical therapy [29],

(iii) Immunosuppressed patient and

(iv) Absence of a laboratory diagnosis to indicate oral salivary microbial status prior to the surgical act [30] (Figure 1).

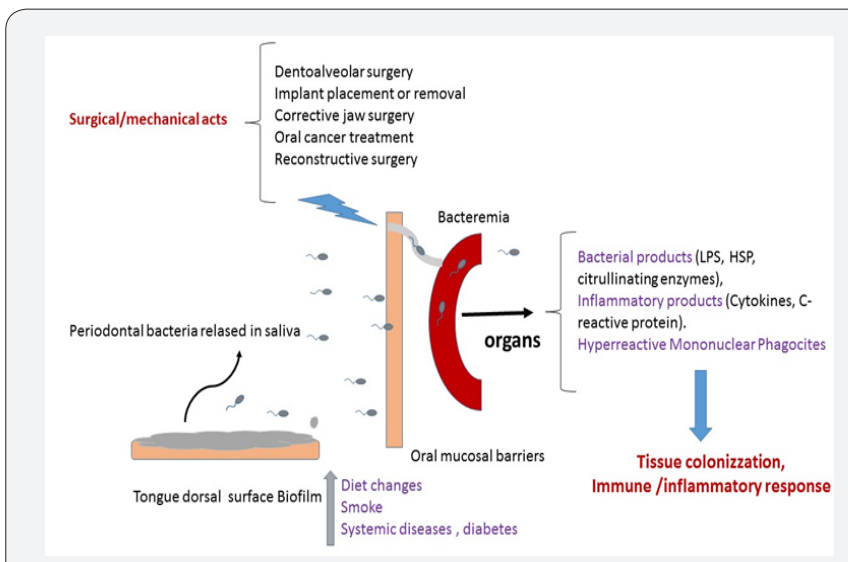

Figure 1: Schematic representation of relationship between surgical oral procedures and systemic diseases related to oral bacteria.

\section{Conclusion}

Current evidence suggests that different systemic autoimmune or cardiovascular diseases, as well as oral -intestinal cancer, are related to different oral bacteria. In particular, recent years have seen the emergence of various anaerobic bacteria structured as biofilm in dental plaque and in tongue microbiota. These bacteria and their products may enter the bloodstream, thereby causing many systemic diseases and, sometimes, they are related to degenerative, autoimmune syndromes. Surgical procedures could interfere with the normal protective mucosa barrier and expose the patient to opportunistic oral bacteria. An effective control of systemic infections in oral surgery practice requires an operative protocol aimed at achieving specific objectives in: the pre-surgical step, during surgical procedure, and in the post-surgical step, including microbiological analysis, an accurate antimicrobial prophylaxis and a correct surgical procedure to avoid minimal lesions or traumas in the oral tissues.

\section{References}

1. Redmond AM, Meiklejohn C, Kidd TJ, Horvath R, Coulter C (2007) Endocarditis after use of tongue scraper. Emerg Infect Dis 13(9): 14401441.

2. Faveri M, Feres M, Shibli JA, Hayacibara RF, Hayacibara MM,, et al. (2006) Microbiota of the dorsum of the tongue after plaque accumulation: an experimental study in humans. J Periodontol 77(9): 1539-1546.

3. Christina J Adler, Richard Malik, Gina V Browne, Jacqueline M Norris (2016) Diet may influence the oral microbiome composition in cats. Microbiome 4(1): 23.

4. Tsigarida AA, Dabdoub SM, Nagaraja HN, Kumar PS (2015) The Influence of Smoking on the Peri-Implant Microbiome. J Dent Res 94(9): 1202-1217. 
5. Kurita-Ochiai T, Jia R, Cai Y, Yamaguchi Y, Yamamoto M (2015) Periodontal Disease-Induced Atherosclerosis and Oxidative Stress. Antioxidants (Basel) 4(3): 577-590.

6. Fåk F, Tremaroli V, Bergström , Bäckhed F (2015) Oral microbiota in patients with atherosclerosis. Atherosclerosis 243(2): 573-578.

7. Rath SK, Mukherjee M, Kaushik R, Sen S, Kumar M (2014) Periodontal pathogens in atheromatous plaque. Indian J Pathol Microbiol 57(2): 259-264.

8. Sparks Stein P, Steffen MJ, Smith C, Jicha G, Ebersole JL, et al. (2012) Serum antibodies to periodontal pathogens are a risk factor for Alzheimer's disease. Alzheimers Dement 8(3): 196-203.

9. Germano Orrù, Eleonora Casula, Cristina Demontis, Cornelio Blus, Serge Szmukler-Moncler, et al. (2017) Periodontal microbiota of Sardinian children: comparing 200-year-old samples to presentday ones. Journal of Pediatric and Neonatal Individualized Medicine (JPNIM) 6(1): 3.

10. Gürcan Ş, Ünlü S, Kuloğlu F, Karadenizli A, Kuşkucu MA (2016) Microbiological approach to a possible infective endocarditis case caused by Aggregatibacter actinomycetemcomitans. Mikrobiyol Bul $50(2): 315-321$

11. Paturel L, Casalta JP, Habib G, Nezri M, Raoult D (2004) Actinobacillus actinomycetemcomitans endocarditis. Clin Microbiol Infect 10(2): 98118.

12. Konig MF, Abusleme L, Reinholdt J, Palmer RJ, Teles RP, et al. (2016) Aggregatibacter actinomycetemcomitans-induced hypercitrullination links periodontal infection to autoimmunity in rheumatoid arthritis. Sci Transl Med 8(369): 369ra176.

13. Nakano K, Nemoto H, Nomura R, Inaba H, Yoshioka H, et al. (2009) Detection of oral bacteria in cardiovascular specimens. Oral Microbiol Immunol 24(1): 64-68.

14. Tomoyuki Ogataa, Teruo Uratab, Daisuke Nemotoc, Shigemi Hitomi (2017) Thoracic empyema caused by Campylobacter rectus. J Infect Chemother 23(3): 185-188.

15. Gauthier S, Tétu A, Himaya E, Morand M, Chandad F, et al. (2011) The origin of Fusobacterium nucleatum involved in intra-amniotic infection and preterm birth. J Matern Fetal Neonatal Med 24(11): 1329-1332.

16. Yu J, Chen Y, Fu X, Zhou X, Peng Y, et al. (2016) Invasive Fusobacterium nucleatum may play a role in the carcinogenesis of proximal colon cancer through the serrated neoplasia pathway. Int J Cancer 139(6): 1318-1326.

17. Gholizadeh P, Eslami H, Yousefi M, Asgharzadeh M, Aghazadeh M, et al. (2016) Role of oral microbiome on oral cancers, a review. Biomed Pharmacother 84: 552-558.

18. Han YW (2015) Fusobacterium nucleatum: a commensal-turned pathogen. Curr Opin Microbiol 23: 141-147.
19. Shimada A, Kobayashi T, Ito S, Okada M, Murasawa A, et al. (2016) Expression of anti-Porphyromonas gingivalis peptidylarginine deiminase immunoglobulin $\mathrm{G}$ and peptidylarginine deiminase-4 in patients with rheumatoid arthritis and periodontitis. J Periodontal Res 51(1): 103-111.

20. Olsen I, Taubman MA, Singhrao SK (2016) Porphyromonas gingivalis suppresses adaptive immunity in periodontitis, atherosclerosis, and Alzheimer's disease. J Oral Microbiol 8: 33029.

21. Nipuna Parahitiyawa, LjJin, Wk Leung, Lakshman Perera Samaranayake, Wing-Cheong Yam (2009) Microbiology of odontogenic bacteremia: beyond endocarditis. Clin Microbiol Rev 22(1): 46-64.

22. Suzuki J, Imai Y, Aoki M, Fujita D, Aoyama N, et al. (2014) Periodontitis in cardiovascular disease patients with or without Marfan syndrome-a possible role of Prevotella intermedia. PLoS One 9(4): e95521.

23. Leishman SJ, Ford PJ, Do HL, Palmer JE, Heng NC, et al. (2012) Periodontal pathogen load and increased antibody response to heat shock protein 60 in patients with cardiovascular disease. J Clin Periodontol 39(10): 923-930.

24. Chukkapalli SS, Rivera-Kweh MF, Velsko IM, Chen H, Zheng D, et al. (2015) Chronic oral infection with major periodontal bacteria Tannerella forsythia modulates systemic atherosclerosis risk factors and inflammatory markers. Pathog Dis 73(3).

25. Oliveira FA, Forte CP, Silva PG, Lopes CB, Montenegro RC, et al. (2015) Molecular Analysis of Oral Bacteria in Heart Valve of Patients with Cardiovascular Disease by Real-Time Polymerase Chain Reaction. Medicine (Baltimore) 94(47): e2067.

26. Riviere GR, Riviere KH, Smith KS (2002) Molecular and immunological evidence of oral Treponema in the human brain and their association with Alzheimer's disease. Oral Microbiol Immunol 17(2): 113-118.

27. Donley TG, Donley KB (1988) Systemic bacteremia following toothbrushing: a protocol for the management of patients susceptible to infective endocarditis. Gen Dent 36(6): 482-484.

28. Raber-Durlacher JE, Laheij AM, Epstein JB, Epstein M, Geerligs GM, et al. (2013) Periodontal status and bacteremia with oral viridans streptococci and coagulase negative staphylococci in allogeneic hematopoietic stem cell transplantation recipients: a prospective observational study. Support Care Cancer 21(6): 1621-1627.

29. Matteo Erriu, Francesca Maria Giovanna Pili, Enrica Tuveri, Daniela Pigliacampo, Alessandra Scano, et al. (2013) Oil Essential Mouthwashes Antibacterial Activity against Aggregatibacter actinomycetemcomitans: A Comparison between Antibiofilm and Antiplanktonic Effects. Int J Dent 2013: 164267.

30. Germano Orrù, Mario Francesco Marini, Maria Laura Ciusa, Daniela Isola, Marina Cotti, et al. (2006) Usefulness of real time PCR for the differentiation and quantification of 652 and JP2 Actinobacillus actinomycetemcomitans genotypes in dental plaque and saliva. BMC Infect Dis 6: 98

\begin{tabular}{|l|}
\hline \multicolumn{1}{|c|}{ Your next submission with Juniper Publishers } \\
will reach you the below assets \\
- Quality Editorial service \\
- Swift Peer Review \\
- Reprints availability \\
- E-prints Service \\
- Manuscript Podcast for convenient understanding \\
- Global attainment for your research \\
- Manuscript accessibility in different formats \\
( Pdf, E-pub, Full Text, Audio) \\
- Unceasing customer service \\
Track the below URL for one-step submission \\
https://juniperpublishers.com/online-submission.php \\
\hline
\end{tabular}

